| Volume: 5 | Number: 2 | October 2020| E-ISSN: 2503-4405|P-ISSN: 2580-3441|

\title{
Improving English Present Tenses Comprehension by Using English-dubbed Anime Yu-Gi-Oh ARC-V
}

\author{
Aswir $^{1}$, Afif Alwan Sabiq ${ }^{2}$ \\ Universitas Muhammadiyah Jakarta, \\ aswir@umj.ac.id ${ }^{1}$, afifygbaru@gmail.com²
}

\begin{abstract}
The research aimed to analyze the improvement of English Present Tense comprehension through visual material, English-dubbed anime. The research was conducted in the Social Classes of SMAN 6 Tangsel. Researcher chose two classes as Control and Experimental class. The Social Class I (IPS 1) would be the Control class and the Social Class III (IPS 3) would be the Experimental class. The researcher used purposive sampling techniqueby choosing 30 students of each class and conducted both pre-test and post-test to gather the research data. While the control class used conventional or traditional technique on learning English Present Tense, the experimental class was using English-dubbed anime on learning the Tenses. The research lasted for three weeks and researcher compared the results of pre-test and post-test through SPSS 22 to conclude the results of research. The Experimental class results would be the conclusion of research as this class used English-dubbed anime during the lesson. After analyzing the data through statistic method Pairedsamples T-test, the t-value of pre-test and post-test Experimental class is 9.598 and $t$ value of Experimental class $d f$ is 2.034. As the t-value of experimental class was higher than $\mathrm{t}$-value of $d f(9.598>2.034)$, researcher concluded that using English-dubbed anime for students in the classroom was effective to improve the comprehension of Present Tenses.
\end{abstract}

Keyword: visual material, Present Tense, English-dubbed animation.

\section{INTRODUCTION}

Present Tenses are of tenses that are used in English. Gonzales (2014:44) adds more that Present Tenses explains an action or event that occurs in current time, the habitual action, and general truth. Because of its function, Present Tenses are most used tenses in English. This is fact is also supported by statement of Singh (2010:33-34) and Herring (2016:629). In their statements, they explain that there are technically two official tenses in English, present tensesand past tenses. They also explain the reason of their statements that verbs in these tenses have both present form for Present Tenses and past form for Past Tenses in verbs. However, verbs that are in these tenses don't have forms which reflect the future or pastfuture forms. Thus, Present Tenses become the most used tenses in English.

However, learning and understanding Present Tenses are difficult matters for English learners. The one of matter that causes the difficulties of learning Grammar is the lack of exposure of target language. Gilakjani (2011:2) explains that one of several reasons why it is difficult to learn English including Grammar including Present Tense are the lack of motivation and exposure of target language. Then, English learners become reluctant and fear on learning Present Tense.

\section{ENGLISH EDUCATION}

Journal of English Teaching and Research 
Furthermore, researcher decides to conduct research on learning technique that gives more motivation and exposure.

There is previous research that researcher uses as the basis of his research and the previous research involves visual material in learning process. Mushtaq and Zehra (2016:77-86) used visual material in their research as they conducted research to improve the Tenses and other Grammar rules on students. They showed various clips of animation named Tangled in the classroom and learnt these clips together with students. After several weeks, they compared the worksheet results with student previous test. They found the improvement on student Grammar comprehension and motivation. Then, they concluded that English-dubbed animation can improve student comprehension.

Later, Abdo and Al-Awabdeh (2017:1416-1422) explains as they compared the results between English-dubbed animation and traditional technique, there was improvement in student comprehension for Past Tenses because they found out that there was decrease of student grammatical errors in post-test compared pretest. They also added that visual material enhanced student thought and students were motivated and could comprehend the Tense easily during the lesson.

Then, Isna (2018:51-56) conducted similar research related to visual material such as animation in English lesson including Tenses. After analyzing the data and putting the results in diagram, she explained that animation or movie could be used as teaching tools for learning and comprehending Tenses in English. Then, she also concluded that Upmovie was appropriate additional material for teaching English in Indonesian school because the movie motivated students on learning process. In additional source, Saindra and Mutiarani (2018:60-62) also conducted similar research as they used graphic organizer to improve student's skill including Tenses. In the comparison of pre-test and post-test results, students had the improvement in English including Tenses.

In recent research, Mahmudah and Izzah (2019:89-93) conducted research to improve student's understanding in Past Tenses by using visual material of VOA Youtube Channel. After analyzing statistic results of pre-test and post-test, visual material of VOA Youtube Channel was effective on giving more exposure and learning sources to students and there was improvement in student's Past Tenses understanding. This recent research also showed that visual material was effective on improving student's understanding in Tenses.

Based on the previous research at preceding paragraphs, researcher decides to conduct similar research to the previous research. As the visual material learning technique gives motivation and exposure better than traditional technique, researcher will use visual material in research and teach the students through visual material. The visual material that researcher will use is English-dubbed anime series.

Wikipedia explains the definition of anime is still disputed by many language experts. In popular slang, Anime is used to refer The Animation of Japan, animation created in Japan, or Unique Japan-Visual Products. In English term, anime is noun that is usually used as common noun and has uncountable form. Prior to spread of anime word, people used the term Japanimation in 1970s and 1980s. Then, people started using anime to refer Japanimation that was used to distinguish and identify Japanese animation. Despite being popular term, anime word has been criticized by several experts including Hayao Miyazaki. He dislikes anime word because he 
believes the term represents the lack of animator motivation, moral value of visual products, the uniqueness of material, etc. Furthermore, anime becomes popular product in foreign countries and many translators replace the Japanese language into other foreign language including English. Thus, there is anime called Englishdubbed anime. The title of English-dubbed anime that researcher will use is $\mathrm{Yu}$-GiOh $A R C-V$.

Yu-Gi-Oh Wikiaexplainsthat The Yu-Gi-Oh ARC-V is anime series and the $4^{\text {th }}$ anime adaption began airing on $6^{\text {th }}$ April 2014 and ended on 26 $6^{\text {th }}$ March 2017. This anime was directed by Katsumi Ono and animated by Gallop. This anime succeeded the previous anime adaption which was ZEXAL. This anime focuses on the protagonist YuyaSakakiand introduces new type of summoning method and new card similar to previous anime adaption. The new card which is introduced named Pendulum Card and the new summoning method is called Pendulum Summon. This anime also has manga adaption that has different story. Later, this is succeeded by Yu-Gi-Oh VRAINS which also introduces new card and new summoning method. Unlike other anime adaptions, this anime shows every summoning method from Yu-Gi-Oh! TCG alongside the Pendulum Summon. Yu-Gi-Oh ARC-V has 148 episodes that have been dubbed into English and the series was approved by foreign countries thus aired in South Korea, German, Canada, Australia, United States, etc. due to being completed in English-dubbed version, researcher decides to choose this title because other researcher hasn't chosen this visual material title.

Researcher decides to use English-dubbed anime series as the previous researcher hasn't chosen this English-dubbed visual material and researcher intends to find out if this kind of visual material can give motivation and exposure to students better than traditional technique. The research focuses on improving student's Present Tense comprehension through English-dubbed anime and researcher will use test to gather the results. Because the research only focuseson Present Tense, researcher will not include other English Tenses and researcher has only intention to improve Present Tense Comprehension of student. Thus, researcher names the research and article in title Improving English Present Tenses Comprehension by Using English-dubbed Anime Yu-Gi-Oh ARC-V.

\section{METHOD}

The researcher used quantitative method and quasi-experimental design in research. Howard (2014:1) and Creswell (2018:215) explainedthat quantitative method used hypotheses, variables and statistic formula to analyze the results. Then, in quasi-experimental design, research needed to give stimulus in research process, but researcher didn't help the participant too much and researcher only facilitated students with learning media in classroom. As for English-dubbed anime, researcher used English-dubbed anime named Yu-Gi-Oh ARC-V series. Researcher would use several episodes in classroom. The series mainly used Present Tense in the English-dubbed version and researcher decided to use this series as visual material in research.

Then, researcher composed population and sample in research. Creswell (2018:204) notes that population is a group of individuals and those individuals have same characteristics to each other. Based on this definition, researcher concluded that the population was X IPS classes in SMAN 6 Tangsel.

After choosing the population, researcher selected the sample of research. Creswell (2018:204-295) explains that sample is a sub-group of population which

\section{ENGLISH EDUCATION}

Journal of English Teaching and Research 
researcher plans to study as the representation of population. In other words, sample is a small portion of population that researcher uses as the participant of research to gather the data.

The sample for research wasX IPS 1 and X IPS 3 from the population. The X IPS 1 would be control class and the X IPS 3 would be experimental class. As researcher used purposive sampling technique, he limited the number of students in each class. Researcher would use 30 students in each class as sample for collecting data during the test.

Then, Creswell (2018:215) explained that quantitative method needed the research variables, the researcher concluded two variables in research as the researcher would use quantitative method in research. The research had two variables, such as (1) independent variable and (2) dependent variable. The independent variable of the research ( $\mathrm{x}$ variable) was JADS "Yu-Gi-Oh ARC-V". Then, in this research, the JADS was used by the researcher as alternative strategy on teaching present tenses comprehension to tenth-class of SMAN 6 Kota Tangerang Selatan. The dependent variable of the research (Y variable) was student's comprehension in present tenses.

As researcher needed to gather the data, the method of collecting data was pre-test and post-test. Researcher would give pre-test to experimental and control classes before using the English-dubbed anime "Yu-Gi-Oh ARC-V" in the experimental class during the lesson and researcher would use ordinary technique in control class. Then, after several times using anime series in the class, researcher would give post-test to the learners in experimental and control classes.

After collecting the data, researcher needed to analyze the data through statistic formula. The method of analyzing the data was t-test. Researcher would use IBM SPSS 22 and Microsoft Excel as the media to analyze the data. The method would test the possibility of hypotheses that were being tested in the research and this method would determine which hypothesis was possible for the result of research. The structures of analysis were:

(1) $X=Y$

(2) $\mathrm{X} \neq \mathrm{Y}$

$\mathrm{X}$ : Independent Variables

Y : Dependent Variables

$=:$ Related

$\neq$ : Not Related

(1) $\mathrm{X}=\mathrm{Y}$ :The variables influence each other and cause the relationship between result and hypothesis.

(2) $X \neq Y$ :The variables don't influence each other and don't cause relationship between result and hypothesis.

Table 1.1 Structure of the Variables and Hypotheses Analysis

Based on this table, researcher would analyze whether Independent Variables (X) influence Dependent Variables (Y). When Independent Variables influenced Dependent Variables $(X=Y)$, the Hypothesis would be valid and 
|Volume: 5 | Number: 2 | October 2020| E-ISSN: 2503-4405|P-ISSN: 2580-3441|

research was success. However, Independent Variables didn't influence Dependent Variables $(\mathrm{X} \neq \mathrm{Y})$, the Hypothesis would be invalid and research wasn't success.

\section{RESULTS AND DISCUSSION}

Researcher would conduct the research in two class, Control and Experimental class. The structure of research in each class was:

Table 1.2 Structure of Research of Control and Experimental Class

\begin{tabular}{|l|l|l|l|l|}
\hline $\begin{array}{c}\text { Experiment } \\
\text { al Class }\end{array}$ & Pre-test & Treatment & $\begin{array}{c}\text { Post- } \\
\text { test }\end{array}$ & $\begin{array}{c}\text { The Result } \\
\text { of Research }\end{array}$ \\
\hline $\begin{array}{c}\text { Control } \\
\text { Class }\end{array}$ & Pre-test & Treatment & $\begin{array}{c}\text { Post- } \\
\text { test }\end{array}$ & $\begin{array}{c}\text { The Result } \\
\text { of Research }\end{array}$ \\
\hline
\end{tabular}

Based on this table, researcher would conduct pre-test in each class before giving the treatment to each class. After conducting pre-test, researcher would conduct treatment in each class. Each class would obtain different treatment since the research used Quasi-Experimental Design. The treatment would last for several weeks. Then, researcher would begin analyzing pre-test and post-test results after completing the research.

Before analyzing data through SPSS, researcher compared the percentage result of each class. Researcher had to explain that there was difference between Control and Experimental class. During the research period as the researcher was done on checking the pre-test, researcher also could see the difference between experimental and control class. Students in control class were able to distinguish and learn the Present Tense better than the student of experimental class. Control classwas able to choose correct answer the test. Thus the class could obtain higher score in games, training worksheet, etc. Experimental class wasn't able to choose correct answer in the test because they couldn't distinguish each difference of Present Tense type. Experimental class had problems on comprehending material.

Then, researcher held the discussion of pre-test's results in each class. In discussion, Control class explained that they still could comprehend the test while they still had few questions that they didn't understand. Experimental class explained that they only understand few questions and they couldn't choose correct answer in the majority of question. In further discussion, experimental class explained its reason why the class couldn't obtain higher score than control class.

Experimental class explained that they hadn't understood and couldn't comprehend each type of Present Tenses which was composed in Simple Present, Present Continuous, Present Perfect, and Present Perfect Continuous Tense. They also added that they only understood Simple Present and Present Continuous because they still often saw and used this type of Present Tense. But they still couldn't understand other type as they rarely see and used other type. They also said while they understood the first two types, they still lacked in theory of Present Tense and they chose wrong answer because they also didn't understand the structure of Present Tense.

\section{ENGLISH EDUCATION}

Journal of English Teaching and Research 
In further explanation, experimental class also added that the English teacher didn't teach the material properly. The teacher explained the material to students, but teacher didn't seem to care whether or not students understood the material. Teacher also didn't give further explanation on teaching material and simply gave homework or test as the tool to help students. In short explanation, teacher didn't give more exposure or motivation on teaching material in class.

When researcher held the discussion in Control class, the class gave different answer and explanation. The control class explained that they still understood the each type of Present Tense despite the fact that they only chose several correct answers. In further explanation, they added that they managed to motivate themselves while teacher didn't teach them properly. They also explained that they always tried being independent and capable without teacher's help and searched more exposure to learn the material. Thus they managed to obtain higher scores than experimental class scores. Then, researcher made the tables which contained the example of Control and Experimental classes differences based on student of each class:

A. Before Post-test Percentage Results

\begin{tabular}{|c|c|c|c|c|c|}
\hline \multirow[t]{2}{*}{ CLASS } & \multirow[t]{2}{*}{ NAME OF STUDENTS } & \multicolumn{2}{|c|}{$\begin{array}{c}\text { PERCENTAGE } \\
\text { CORRECT ANSWER }\end{array}$} & \multicolumn{2}{|r|}{ PRE-TEST } \\
\hline & & SP & $\mathrm{PC}$ & PP & PPC \\
\hline $\begin{array}{l}\text { Experimental } \\
\text { Class }\end{array}$ & Student A & $50 \%$ & $\%$ & $0 \%$ & $\%$ \\
\hline Control Class & Student B & $80 \%$ & $\%$ & $\%$ & $\%$ \\
\hline
\end{tabular}

Table 1.3 Percentage ofPre-testCorrect Answer

SP: Simple Present

PC: Present Continuous

PP: Present Perfect

PPC: Present Perfect Continuous

\begin{tabular}{|c|c|c|}
\hline CLASS & NAME OF STUDENTS & $\begin{array}{l}\text { THE PERCENTAGE OF ERRORS } \\
\text { SENTENCE }\end{array}$ \\
\hline $\begin{array}{l}\text { Experimental } \\
\text { Class }\end{array}$ & Student A & $\begin{array}{l}\text { 1. Simple Present: } \\
\text { Rain fall from the cloud. } \\
\text { I think Helen are always lucky. } \\
\text { She always had to bed early. } \\
\text { I written a letter for my mom. } \\
\text { We eaten this food here. (wrong) } \\
(50 \%) \\
\text { 2. Present Continuous: } \\
\text { It is } 11.00 \text { PM. Irina been sleeping in } \\
\text { her bedroom. } \\
\text { Were Mary reading a book in her } \\
\text { classroom. } \\
\text { Susan and Susanna am writing } \\
\text { poems for an English subject. } \\
\text { The parrots calling my name. }\end{array}$ \\
\hline
\end{tabular}




\begin{tabular}{|c|c|c|}
\hline & & $\begin{array}{l}\text { She look a butterfly. } \\
\text { They were having a good time. } \\
\text { Kristin washing her cloth. (wrong) } \\
\text { (70\%) } \\
\text { 3. Present Perfect: } \\
\text { I has studied for two hours. } \\
\text { We has here since yesterday. } \\
\text { Diana are sung this song. } \\
\text { Steven has write a new book. } \\
\text { There were a war in United States. } \\
\text { I has gone to school. } \\
\text { Mrs. Oh working a teacher since } \\
\text { 2002. } \\
\text { She known him for two months. } \\
\text { I hasn't eaten since I got up. } \\
\text { They been here before. (wrong) } \\
\text { (100\%) } \\
\text { 4. Present Perfect Continuous: } \\
\text { That's because tourism itself were } \\
\text { declining since last year. } \\
\text { Eko work on this report for two } \\
\text { days. } \\
\text { Vita's family life in poverty. } \\
\text { What am you doing for the last } 30 \\
\text { minutes? } \\
\text { I has sat here for two hours. } \\
\text { Al wearing glasses since he was ten. } \\
\text { They has been looking you. } \\
\text { They has listening for three hours. } \\
\text { (wrong) ( } 90 \% \text { ) }\end{array}$ \\
\hline Control Class & Student B & $\begin{array}{l}\text { 1. Simple Present: } \\
\text { I think Helen are always lucky. } \\
\text { We eatingthis food here. (wrong) } \\
(20 \%) \\
\text { 2. Present Continuous: } \\
\text { It is } 11.00 \text { PM. Irina been sleeping in } \\
\text { her bedroom. } \\
\text { Susan and Susanna am writing } \\
\text { poems for an English subject. } \\
\text { They were having a good time. } \\
\text { Kristin washing her cloth. (wrong) } \\
\text { (40\%) } \\
\text { 3. Present Perfect: } \\
\text { Diana are sung this song. } \\
\text { Steven has write a new book. } \\
\text { I has gone to school. } \\
\text { Mrs. Oh working a teacher since } \\
2002 \text {. } \\
\text { I hasn't eaten since I got up. }\end{array}$ \\
\hline
\end{tabular}




\begin{tabular}{|l|l|}
\hline \multirow{5}{*}{} & They been here before. (wrong) \\
& (50\%) \\
& 4. Present Perfect Continuous: \\
That's because tourism itself were \\
declining since last year. \\
What am you doing for the last 30 \\
minutes? \\
Al wearing glasses since he was ten. \\
They has been looking you. \\
They has listening for three \\
hours.(wrong) (50\%)
\end{tabular}

Table 1.4 Errors ofPre-testAnswer

These two tables clarified that Present Tense comprehension of students was below average. The pre-test contained 40 questions. Each type of Present Tense was presented in 10 questions and researcher used percentage to show both correct and errors in pre-test results in simple number. Through percentage of pre-test correct answer, both classes still understood Simple Present better than other type. However, Experimental class had 50\% of comprehending Simple Present while Control class had $80 \%$ in its percentage. In Present Continuous, Control class obtained $60 \%$ and Experimental class only managed to obtain $30 \%$ which was below the latter. In Present Perfect, Control class obtained 50\% and Experimental class obtained 0\%. In Present Perfect Continuous, Control class still managed to obtain 50\% and Experimental class only managed to obtain $10 \%$.

Through errors of pre-test answer, both classes still understood the structure of Simple Present better than other type. Experimental class had 50\% errors on comprehending Simple Present structure while Control class had 20\% in its errors percentage. In Present Continuous, Control class obtained $40 \%$ errors on comprehending its structure and Experimental class obtained70\% which was above the latter. In Present Perfect, Control class obtained 50\% errors and Experimental class obtained $100 \%$ errors in its structure. In Present Perfect Continuous, Control class still managed to obtain 50\% and Experimental class obtained $90 \%$ for error percentage in its structure.

Then, researcher conducted research in order to improve both Control and Experimental class. Shortly, after conducting pre-test, researcher began teaching both classes by using different method as researcher used English-dubbed anime in Experimental class and traditional technique in Control class. Researcher took 30 minutes on teaching material in both classes and 20 minutes for discussion, homework, etc. The researcher prioritized Present Continuous, Present Perfect, and Present Perfect Continuous in the lesson time as the majority of students needed to improve the structure of tenses except the Simple Present. The activity lasted for several weeks.

After several weeks teaching, Researcher analyzed improvement of Experimental class. Experimental class was able to learn as fast as Control class. As researcher gave Experimental class training sheet in each week, Experimental class was able to score higher results before using English-dubbed anime. The students of Experimental class were motivated more due to using English-dubbed anime as material was more fun than traditional technique. The students also said that they were no longer confused with Present Tense theory or structure and could 
understand each type of Present Tense better through visual material. Thus, researcher the tables that contained the example of Control and Experimental class based on student of each class differences:

B. After Post-test Percentage Results

\begin{tabular}{|c|c|c|c|c|c|}
\hline \multirow[t]{2}{*}{ CLASS } & \multirow[t]{2}{*}{ NAME OF STUDENTS } & \multicolumn{2}{|c|}{$\begin{array}{c}\text { PERCENTAGE } \\
\text { CORRECT ANSWER }\end{array}$} & \multicolumn{2}{|c|}{ POST-TEST } \\
\hline & & SP & PC & $\mathrm{PP}$ & PPC \\
\hline $\begin{array}{l}\text { Experimental } \\
\text { Class }\end{array}$ & Student A & $80 \%$ & 90 & $\%$ & $\%$ \\
\hline Control Class & Student B & $\%$ & $\begin{array}{ll} & 100 \\
\% & \end{array}$ & $0 \%$ & $\%$ \\
\hline
\end{tabular}

Table 1.5 Percentage of Post-test Correct Answer

SP: Simple Present

PC: Present Continuous

PP: Present Perfect

PPC: Present Perfect Continuous

\begin{tabular}{|c|c|c|}
\hline CLASS & NAME OF STUDENTS & $\begin{array}{l}\text { THE PERCENTAGE OF ERRORS } \\
\text { SENTENCE }\end{array}$ \\
\hline $\begin{array}{l}\text { Experimental } \\
\text { Class }\end{array}$ & Student A & $\begin{array}{l}\text { 1. Simple Present: } \\
\text { Cat to buy the fish from food shop. } \\
\text { Heam cooking food at Padang } \\
\text { Restaurant. (wrong) (20\%) } \\
\text { 2. Present Continuous: } \\
\text { What is we doing? (wrong) (10\%) } \\
\text { 3. Present Perfect: } \\
\text { She am looking this song. } \\
\text { Jack am resting the new job. } \\
\text { They is going to German. } \\
\text { Miss Julie am eating since morning. } \\
\text { (wrong) ( } 40 \% \text { ) } \\
\text { 4. Present Perfect Continuous: } \\
\text { He am staying this village for three } \\
\text { years. } \\
\text { We is eating in this restaurant since } \\
\text { yesterday. } \\
\text { William food cake for his brother. } \\
\text { I we headache, my head hurts. } \\
\text { The monkey and bird am staying on } \\
\text { the tree. } \\
\text { She am looking her boyfriend for } \\
\text { three months.(wrong) ( } 60 \% \text { ) }\end{array}$ \\
\hline Control Class & Student B & $\begin{array}{l}\text { 1. Simple Present: } \\
\text { None. (wrong) (0\%) } \\
\text { 2. Present Continuous: } \\
\text { None. (wrong) (0\%) } \\
\text { 3. Present Perfect: }\end{array}$ \\
\hline
\end{tabular}




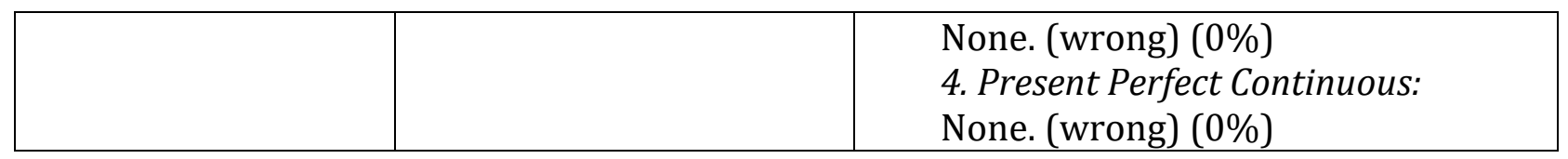

Table 1.6 Errors of Post-test Answer

Similar to pre-test, these two tables clarified that Present Tense comprehension of students. The post-test contained 40 questions. Each type of Present Tense was presented in 10 questions and researcher used percentage to show both correct and errors in pre-test results in simple number. Through percentage of post-test correct answer, both classes showed improvement in Present Tense comprehension. Experimental class had $80 \%$ of Simple Present while Control class had $100 \%$ in its percentage. In Present Continuous, Control class obtained $100 \%$ and Experimental class managed to obtain $90 \%$ which was above previous result. In Present Perfect, Control class still obtained 100\% and Experimental class obtained $60 \%$ in its percentage. In Present Perfect Continuous, Control class still managed to obtain $100 \%$ and Experimental class managed to obtain $40 \%$ which was also above previous result. While Control class still had higher scores, Experimental class improved their results significantly.

Through errors of post-test answer, both classes still understood the structure of Simple Present better than other type. Experimental class had 20\% errors on comprehending Simple Present structure while Control class had 0\% in its errors percentage. In Present Continuous, Control class obtained $0 \%$ errors on comprehending its structure and Experimental class obtained $10 \%$ which was above the latter. In Present Perfect, Control class obtained $0 \%$ errors and Experimental class obtained $40 \%$ errors in its structure. In Present Perfect Continuous, Control class still managed to obtain $0 \%$ and Experimental class obtained $60 \%$ for error percentage in its structure. While Control class had perfect comprehension results, Experimental class improved its comprehension in Present Tense structure significantly. The results of Experimental class showed that English-dubbed anime had the positive impact for students.

Then, researcher added the difference of these two classes through pre-test and post-test score. During pre-test, control class had the lowest score at 23 point and the control classobtained the highest score at 88 point. Then, researcher compared the pre-test results of experimental class. Experimental class obtained the lowest score at 18 point while this class had the highest score at 80 point. Based on these results, researcher could see the difference between control and experimental class.

After post-test, control class obtained the lowest score at 60 point while this class had the highest score at 100 point. Experimental class still had the lowest score at 18 point, but this class obtained the highest score at 100 point. While experimental class still had the lowest score in same number, the results showed that there was improvement in experimental class comprehension in Present Tense. Researcher also added the difference between two classes through pre-test and post-test mean calculation. The calculations are: 


\begin{tabular}{|c|c|c|c|c|c|}
\hline & & Mean & $\mathrm{N}$ & $\begin{array}{l}\text { Std. } \\
\text { Deviation }\end{array}$ & $\begin{array}{l}\text { Std. } \\
\text { Error } \\
\text { Mean }\end{array}$ \\
\hline \multirow[t]{2}{*}{$\begin{array}{l}\text { Pair } \\
1\end{array}$} & $\begin{array}{l}\text { Pre- } \\
\text { test } \\
\text { (X IPS } \\
\text { 1) }\end{array}$ & 50.67 & 30 & 17.810 & 3.252 \\
\hline & $\begin{array}{l}\text { Post- } \\
\text { test } \\
\text { (X IPS } \\
\text { 1) }\end{array}$ & 86.83 & 30 & 13.031 & 2.379 \\
\hline \multirow[t]{2}{*}{$\begin{array}{l}\text { Pair } \\
2\end{array}$} & $\begin{array}{l}\text { Pre- } \\
\text { test } \\
\text { (X IPS } \\
\text { 3) }\end{array}$ & 45.08 & 30 & 12.620 & 2.304 \\
\hline & $\begin{array}{l}\text { Post- } \\
\text { test } \\
\text { (X IPS } \\
\text { 3) }\end{array}$ & 75.50 & 30 & 19.799 & 3.615 \\
\hline
\end{tabular}

Table 1.7 Pre-test and Post-test Mean Results

Researcher explained the difference between these two classes through the mean of its pre-test. The control class pre-test mean was 50.67 while the experimental class pre-test mean was 45.08 while the difference of these mean results were not too much, it was clear that the experimental class was still lacking in its comprehension of tenses and the students of experimental class still needed more improvement so they could increase their average score.

In further statistic, there was difference between the post-test mean. After the test, the control class post-test mean was 86.83 and the experimental class posttest mean was 75.50. While the control class was still higher than experimental class, the latter managed to increase their score thus improve the comprehension in present tense. Then, despite the fact students of control class obtained the better score than in the pre-test as researcher used conventional or traditional technique on teaching material, students of experimental class managed to obtain higher score than in the pre-test as researcher used English-dubbed anime on teaching material. Furthermore,researcher calculated the data through Paired-Samples Ttest in SPSS. The statistic results are: 


\begin{tabular}{|c|c|c|c|c|c|c|c|c|c|}
\hline & & \multicolumn{5}{|c|}{ Paired Differences } & \multirow[b]{3}{*}{$\mathrm{t}$} & \multirow[b]{3}{*}{$\mathrm{df}$} & \multirow{3}{*}{$\begin{array}{r}\text { Sig } \\
. \quad(2- \\
\text { tailed })\end{array}$} \\
\hline & & \multirow[b]{2}{*}{ an $\begin{array}{l}\text { Me } \\
\end{array}$} & \multirow[b]{2}{*}{$\begin{array}{c}\text { Std. } \\
\text { Deviation }\end{array}$} & \multirow{2}{*}{$\begin{array}{l}\quad \text { St } \\
\text { d. } \\
\text { Error } \\
\text { Mean }\end{array}$} & \multicolumn{2}{|c|}{$\begin{array}{l}\quad 95 \% \\
\text { Confidence } \\
\text { Interval of the } \\
\text { Difference }\end{array}$} & & & \\
\hline & & & & & wer $^{\text {Lo }}$ & per ${ }^{U p}$ & & & \\
\hline air 1 & $\begin{array}{l}\quad P \\
\text { re- } \\
\text { test - } \\
\text { Post- } \\
\text { test } \\
\text { X IPS } \\
\text { 3) }\end{array}$ & $\begin{array}{c}- \\
30.000\end{array}$ & $26^{18.2}$ & $26^{3.1}$ & $\begin{array}{c}- \\
36.359\end{array}$ & $\begin{array}{c}- \\
23.641\end{array}$ & $\begin{array}{c}- \\
9.598\end{array}$ & 33 & .00 \\
\hline
\end{tabular}

Table 1.8 Paired-samples T-test

SPSS Indonesia explained, the t-value of (X IPS 3/Experimental class) is -9.598 and the value also became positive due to statistic formula. Then $0.05 / 2$ and the value became 0.025 . The $\mathrm{df}$ was33 so t-value of $d$ fwas 2.034 . As the t-value of pair 2 is higher than t-value of $\mathrm{df}(9.598>2.034)$ researcher concluded that using Englishdubbed anime for students in the classroom is effective to improve their comprehension for present tenses.

Then, based on these calculations and statistics, researcher found that the research had positive impact on improving student's present tense comprehension. As Gilakjani (2011:2) explained that giving more exposure and motivation improved student's comprehension in English Grammar including Present Tense. Researcher also concluded that the results of research were similar to previous research that researcher used as base of this research. As Mushtaq and Zehra (2016:77-86), Abdo and Al-Awabdeh (2017:1416-1422), Isna (2018:51-56), Saindra and Mutiarani (2018:60-62), and Mahmudah and Izzah (2019:8993)proved that visual material was effective on teaching English lesson including English Tenses.

The research showed that English-dubbed anime was effective material and teacher could use this visual material on teaching material in English lesson including present tenses. As the research result was clear, researcher gave the final conclusion that English-dubbed anime would was effective on teaching English Present Tense.

\section{CONCLUSION}

Based on the research that was conducted in SMAN 6 for several weeks, researcher concludes the use of visual media such as JADS or English-dubbed anime is also effective to improve student comprehension in Present Tense. This conclusion is not only based on test score, but also based on statistic calculations 
for research results. The $\mathrm{t}_{\text {-value }}$ of (X IPS 3) is -9.598 and $\mathrm{t}$-value of $d f$ is 2.034. As researcher compares these two $t$-values, the $t$-value of (X IPS 3 ) is higher than $t$-value of $d f$. Based on this result comparison, the visual material English-dubbed anime is effective and comfortable to improve student comprehension in Grammar including Present Tense.

Then, researcher recommends teacher to involve visual material to improve student comprehension in language lesson. Researcher also advises that teacher has to use many varieties of learning and teaching technique to help students so they can comprehend difficult material in lesson. Researcher also reminds the teacher to keep student's mood well by using other method similar to this visual material technique so the students will not be bored during the lesson.

Researcher encourages the other researcher to conduct the research which uses visual material in learning process so they can develop effective technique for language lesson including Grammar and Present Tense.Lastly, researcher hopes this article and its research results can help other researcher as the source of their research that involves visual material in learning technique.

\section{REFERENCES}

Abdo, I. B., \& Al-Awabdeh, A.-H. (2017). Animated Videos Prove to be Beneficial in Teaching English Grammar as EFL: A Neurological Study of How Students Learn and Retain English Grammar. Creative Education. https://doi.org/10.4236/ce.2017.89099

Creswell, John W. (2018) Research Design: Qualitative, Quantitaive, dan Mixed Method Approaches.

Gonzales, Xyli C. (2014). ENGLISH GRAMMAR Master in 30 Days.

Herring, P. (2016). The Farlex Grammar Book: Complete English Grammar Rules FARLEX International.

Isna, N. (2018). AN ANALYSIS OF TENSES USAGE IN ANIMATED MOVIE “UP”: The relevance with 2013 curriculum for teaching EFL at junior high school in Indonesia. Englisia Journal, 5(2), 51. https://doi.org/10.22373/ej.v5i2.2332

Mahmudah, L., \& Izzah, L. (2019). Students' Understanding on Simple Past Tense through VOA Learning English YouTube Channel. English Language in Focus (ELIF), 1(2), 89. https://doi.org/10.24853/elif.1.2.89-94

Mushtaq, H., \& Zehra, T. (2016). Teaching English Grammar through Animated Movies. NUST Journal of Social Sciences and Humanities. https://doi.org/ISSN 2523-0026

Saindra, R. M., \& Mutiarani. (2018). Using Graphic Organizer to Improve Students' Speaking skill. English Language in Focus (ELIF), 1(1).

Pourhosein Gilakjani, A. (2011). A Study on the Situation of Pronunciation Instruction in ESL/EFL Classrooms. Journal of Studies in Education. https://doi.org/10.5296/jse.v1i1.924

Singh, R. . (2010). How To Write Correct English.

White, Howard., Sabarwal, Shagun. (2014). Quasi-experimental Design and Methods. UNICEF Office of Research. Italy.

https://yugioh.fandom.com/wiki/Yu-Gi-Oh! ARC-V(Retrieved November 14, 2019)

https://en.wikipedia.org/wiki/Anime(Retrieved November 21, 2019) www.spssindonesia.com/cara-uji-paired-t-test(Retrieved January 8, 2019)

\section{ENGLISH EDUCATION}

Journal of English Teaching and Research 